in Ukraine using the "natural" and the constructivist approaches. It determines main elements of a qualitatively new paradigm of professional development of the state authorities' personnel in Ukraine, namely: definition of new forms of professional development of the state authorities' personnel in Ukraine (course study, individual training, full-time internship); definition of clear indicators and criteria for assessing the competence of the state authorities' personnel; ensuring the persistent linkage between the results of vocational training and promotion of the state authorities' personnel; legislative regulation of the short-term and longterm goals of professional development of the state authorities' personnel; the selection of separate components of the system of vocational training of state authorities' personnel and the principles of professional training of civil servants, taking into account European experience, mainly: new basic knowledge for all, update of the evaluation system, purposefulness, proactive nature and predictability, practical orientation.

The thesis identifies the priority guidelines for improvement of the system of professional development of the state authorities' personnel in Ukraine, namely: target financing of the professional development of personnel, introduction of a system for assessing the quality of educational services for the development of personnel, monitoring the results of the development of personnel, focusing on strategic forecasting of the professional development of personnel, introduction of pedagogical innovations in the management of professional development of personnel, standardization of professional internships abroad. The process of forming a public-law institute of public administration personnel in Ukraine is revealed.

Key words: administrative procedure, administrative and legal support, frames, training, mechanism, public administration body, public administration, public body.

DOI: $10.33766 / 2524-0323.88 .175-182$

УДК 342.951:61(477)

О. Л. Сіделковський, кандидат медичних наук, керівник клініки «Аксімед» (м. Київ, Україна) e-mail:ols_med@ukr.net (iD https:// orcid.org/0000-0002-4139-4478

\title{
АДМІНІСТРАТИВНО-ПРАВОВА СУТНІСТЬ ПУБЛІЧНОЇ ПОЛТИКИ В КОНТЕКСТІ ФОРМУВАННЯ ЄДИНОГО МЕДИЧНОГО ПРОСТОРУ УКРАЇНИ
}

У статті розглядається адміністративно-правова сутність публічної політики в контексті формування єдиного медичного простору України. Акцентовано увагу на питаннях розвитку медичного права як комплексного правового утворення. Зазначено, що метою формування єдиного медичного простору є належне забезпечення та захист прав пацієнтів при наданні їм медичної допомоги. Зроблено висновок, що ідеологія сучасної медичної реформи, відповідно до якої «гроші ходять за пацієнтом», має дотичність до адміністративно-правових засад формування єдиного медичного простору.

Ключові слова: публічна політика, охорона здоров'я, єдиний медичний простір, медичне право, адміністративне право. 
Постановка проблеми. Станом на сьогодні ми $є$ свідками низки негативних соціально-правових явищ, які мають місце в Україні, зокрема: підвищення показників захворюваності, зниження тривалості та якості життя, зменшення чисельності населення нашої держави, складнощі в організаційноправовому забезпечення охорони здоров'я. Як видається, одним із важливих кроків, спрямованих на подолання цих негативних явищ, може стати створення та підтримка функціонування єдиного медичного простору. Значною мірою це пов'язано із необхідністю вчинення правових кроків, спрямованих на т. зв. «запуск» єдиного медичного простору. А це водночас залежить від публічної політики, яка реалізується суб'єктами владних повноважень.

Аналіз останніх досліджень і публікацій. Проблематика правового регулювання медичної діяльності загалом та формування медичного простору зокрема було предметом системних наукових розвідок 3. Гладуна, Б. Логвиненка, Р. Майданика, Т. Самілик, В. Стеценко, С. Стеценка, Д. Шатковської, Н. Шевчук. Проте наразі об'єктивно недостатньо опрацьованою є наукова та практична проблема адміністративно-правової сутності публічної політики в контексті формування єдиного медичного простору України.

Формування цілей. Метою цієї статті $є$ розкриття загальних рис та особливостей адміністративно-правового забезпечення публічної політики в контексті формування єдиного медичного простору України.

Виклад основного матеріалу. Станом на сьогодні в державі існують державна, комунальна, приватна та відомча медицина. 3 точки зору історії України, її традицій та підходів до правового забезпечення медичної діяльності такий варіант організації охорони здоров'я є виправданим. Проте наразі, коли мова йде про проведення медичної реформи, про необхідність пошуку шляхів забезпечення та захисту прав пацієнтів, актуальним є пошук шляхів до формування єдиного медичного простору. Відтак важливою $є$ належна публічна політика в цій царині. Необхідність наукової розвідки в даному питанні обумовлена такими чинниками:

1) публічна політика - це явище, котре значною мірою залежить від результатів попередніх виборів, проте не в меншій мірі - від адміністративноправового забезпечення ії впровадження в життя;

2) єдиний медичний простір - відносно нове явище для вітчизняної охорони здоров'я і практично нерозроблене (недосліджене) в рамках правової науки загалом та адміністративно-правової зокрема;

3) поєднання необхідності формування єдиного медичного простору 3 проведенням у нашій державі медичної реформи протягом 2016-2019 рр., яка передовсім спрямована на зміну системи фінансування медичної галузі;

4) наявність наразі нормативно-визначеного поділу системи охорони здоров’ я зумовлює певну уніфікацію діяльності відповідних медичних закладів, яка спрямована на забезпечення прав отримувачів медичних послуг.

Варто вказати, що проявом теоретико-методологічної цінності формування єдиного медичного простору $є$ внесення цієї проблематики в простір медичного права - нового комплексного правового утворення. Тут ми солідарні $з$ думкою С. Г. Стеценка, який справедливо зазначає, що предмет 
медичного права - це суспільні відносини, що виникають у процесі здійснення медичної діяльності. У першу чергу під медичною діяльністю необхідно розуміти комплексну систему, що включає організацію охорони здоров'я, надання медичної допомоги в рамках діагностичних, лікувальних i профілактичних заходів, а також контроль якості медичних послуг. Дане визначення медичної діяльності акцентує увагу на тих процесах, у ході яких виникають численні суспільні відносини, що складають предмет медичного права. Перелік таких процесів не може бути вичерпним, оскільки медична наука розвивається, надання медичної допомоги постійно удосконалюється, з'являються нові складові охорони здоров'я, що обумовлює появу нових суспільних відносин. Проте як основа для сприйняття предмету медичного права дане раніше визначення видається виправданим [1, с. 121].

Утім Л. О. Васечко зазначає, що наразі назріла необхідність визначення на доктринальному рівні місця медичного права в системі права України, що актуалізується так-от:

- системна реформа галузі охорони здоров'я в Україні є неможливою без закладення теоретичних основ ії побудови;

- нечіткість та непослідовність державної політики в медичній сфері, відсутність єдиного підходу до подальшого їі розвитку (зокрема, це стосується як традиційних для України питань фінансування сфери охорони здоров'я, iї організаційної побудови, так і дискусії навколо питань медичного страхування, заборони абортів, легалізації евтаназії тощо);

- актуалізація питань правового забезпечення принципово нових для вітчизняного суспільства видів правовідносин (наприклад, у сфері трансплантації органів та тканин);

- необхідність усунення невизначеності, яка породжує дискусію стосовно самостійності галузі медичного права як такої [2, с. 60].

Нам видається, що вище зазначена думка досліднищі слушно стверджує, що наявною є нечіткість та непослідовність державної політики в медичній сфері, відсутній єдиний підхід до подальшого ії розвитку. У цьому сенсі ми вбачаємо необхідність інтенсифікації пошуків шляхів покращення стану справ у цій сфері, адже переконані, що від належно побудованої системи публічного (як сукупності державного та комунального) управління галуззю багато в чому залежить успіх реформи у сфері охорони здоров'я, у тому числі при формуванні єдиного медичного простору. Важливу роль у цьому процесі має відіграти громадськість, яка доволі часто є важливим ініціатором та суб'єктом проведення реформ у державі [3]. Не можна також забувати про запровадження в Україні нових форм представництва та захисту інтересів під час медичної реформи, наприклад, лобіювання, на які вже зверталася увага в українській юридичній науці [7].

Побудова нової системи громадського здоров'я в Україні констатує той факт, що основними чинниками, які характеризують наявну ситуацію в охороні здоров'я України та унеможливлюють дотримання фундаментального права людини на здоров'я та його охорону, є [4]:

- монополізація та бюрократизація управління, яке не забезпечує лідерства, адекватного реагування на потреби людини і суспільства, котрі динамічно змінюються; урахування ризиків та використання наявного потенціалу; 
- правові засади функціонування охорони здоров'я, які не грунтуються на кращих світових практиках функціонування та розвитку систем охорони здоров'я;

- нерозвинені механізми міжсекторальної координації і взаємодії в інтересах здоров' я населення, що зумовлено інституційною та функціональною нерозвиненістю системи громадської охорони здоров'я;

- стрижневою ідеєю побудови національної системи охорони здоров'я $є$ забезпечення цивілізаційного прогресу на засадах пріоритетів духовності, яка в охороні здоров'я втілюється в соціальній справедливості, людиноцентричності та національній безпеці. Громадяни України, а відтак і весь людський ресурс нації, має стати запорукою соціального прогресу загалом;

- нераціональна структура охорони здоров'я, яка характеризується низькою доступністю і якістю необхідних населенню послуг передусім через диспропорційний і некомплексний розвиток елементів, що забезпечують затратні втручання, і водночас виразну слабкість та нерозвиненість складових, що спрямовані на зміцнення здоров'я та профілактику, відновлення здоров'я.

У контексті теми, що ми розглядаємо, важливо акцентувати увагу на справедливій оцінці того, що нерозвиненими є механізми міжсекторальної координації і взаємодії в інтересах здоров'я населення, зумовлені інституційною та функціональною нерозвиненістю системи громадської охорони здоров'я. А це, як нам видається, до певної міри й пояснює вади публічної політики у сфері охорони здоров'я, що, треба думати, призводить до труднощів формування єдиного медичного простору.

3 нашої точки зору, можна провести паралелі між адміністративно-правовим забезпеченням публічної політики щодо формування єдиного медичного простору та запровадженням на законодавчому рівні в Україні обов'язкового медичного страхування. В обох напрямкам на рівні політичних гасел лунають заклики до необхідності такого роду кроків, проте реально, на рівні адміністративно-правових механізмів, це допоки не спрацьовує. Адміністративноправові засади обов' язкового медичного страхування ретельно досліджувала В. Ю. Стеценко, яка зауважувала, що система обов'язкового соціального медичного страхування має переважно риси публічно-правового характеру. Насамперед, це обумовлено особливою увагою держави до даного виду страхування та, відповідно, істотним публічним і, в першу чергу, саме адміністративним впливом на побудову та функціонування системи обов'язкового соціального медичного страхування [5, с. 210].

Значною мірою адміністративно-правове забезпечення публічної політики у сфері охорони здоров'я пов' язане з функціями публічного адміністрування в цій сфері. Цікавою є точка зору Б. О. Логвиненка, який зазначав, що функції публічного адміністрування сферою охорони здоров'я - це сукупність скоординованих дій, які відбивають основні напрями впливу держави та місцевого самоврядування на організацію охорони здоров'я та медичну діяльність. Зважаючи на це визначення, виокремлюються такі ознаки публічного адміністрування сферою охорони здоров' я: 
- по-перше, це сукупність скоординованих дій, що зумовлюються складним багатокомпонентним характером власне медичної системи. Реалізувати практично будь-яку функщію вибірково, нескоординовано $є$ фактично малоймовірним. В іншому випадку це буде не функція публічного адміністрування медициною або вона не стане ефективною та результативною;

- по-друге, вони відбивають основні напрями впливу держави та місцевого самоврядування. Іншими словами, поза межами публічно-правових зусиль держави чи органів місцевого самоврядування функція публічного адміністрування сферою охорони здоров' я громадян не може бути зреалізованою;

- по-третє, об'єктом реалізащії функцій публічного адміністрування $\epsilon$ охорона здоров'я та медична діяльність. Причому якщо перша сприймається переважно як організаційна категорія, спрямована на створення системи, що забезпечуватиме за необхідності «мобілізацію» зусиль медичної складової, то друга здебільшого стосується безпосереднього процесу надання медичної допомоги чи медичної послуги [6, с. 138-139].

Отже, на наше глибоке переконання, публічна політика у сфері охорони здоров'я стосовно формування єдиного медичного простору має перебувати в парадигмі розвитку медичного права України. Адміністративно-правові особливості реалізації публічної політики повинні бути спрямовані на те, щоб пересічний громадянин України міг би реалізувати своє право на отримання медичної допомоги незалежно від місця проживання та належності до тієі чи іншої соціальної групи.

Висновки. Вважаємо за доцільне вказати, що ідеологія сучасної медичної реформи, відповідно до якої «гроші ходять за пацієнтом», має дотичність до адміністративно-правових засад формування єдиного медичного простору. Держава (у широкому розумінні) виділятиме гроші за надані медичні послуги в державні, комунальні, відомчі чи приватні медичні заклади, проте матиме змогу контролювати якість наданих там медичних послуг.

\section{Використані джерела:}

1. Стеценко С. Г. Вступ до курсу «Медичне право України». Лекція. Право України. 2011. № 11-12. C. 120-131.

2. Васечко Л. О. Місце сучасного медичного права у системі права України. Публічне право. 2016. № 3. С. 60-65.

3. Нестерович В. Ф. Види впливу громадськості на прийняття нормативноправових актів. Вісник Луганського державного університету внутрішніх справ імені Е. О. Дідоренка. 2014. № 1. С. 33-39.

4. Побудова нової системи громадського здоров'я в Україні / Офіційний сайт Міністерства охорони здоров'я України. URL: http://www.moz.gov.ua/ua/ portal/pre_20161006_b.html.

5. Стеценко В. Ю. Обов'язкове медичне страхування в Україні (адміністративноправові засади запровадження): Монографія. К.: Атіка, 2010.320 с.

6. Логвиненко Б. О. Публічне адміністрування сферою охорони здоров'я в Україні: теорія і практика: монографія. Київ: «МП Леся», 2017. 244 с. 
7. Нестерович В. Ф. Основні підходи до визначення поняття «лобіювання». Вісник Луганського державного університету внутрішніх справ імені Е. О. Дідоренка. 2010. № 1. C. 50-58.

8. Макушев П.В.Взаємна політична відповідальність державної влади і громадянина в сучасній правовій державі: монографія / В. М. Торяник, П. В. Макушев. Херсон. 2013. 92 с.

9. Правокультурные основы исследования государственной власти: теоретикометодологические, историко-правовые и ценностно-нормативные аспекты: монография / Г. И. Авцинова, В. Я. Любашиц, А. Ю. Мамычев, А. Ю. Мордовцев, А. И. Овчинников и др. М.: Юрлитинформ, 2014. 480 с.

10. Нормотворча діяльність Президента України та іï нормопроектне забезпечення: монографія / О. В. Скрипнюк, В. Л. Федоренко, Ю. Г. Барабаш, Я. О. Берназюк та ін.; за ред. О. В. Скрипнюка і В. Л. Федоренка. К.: НАДУ, 2011. 344 с.

11. Конституція України: прийнята на п'ятій сесії Верховної Ради України 28 червня 1996 року. Відомості Верховної Ради Украӥни. 1996. № 30. Ст. 141.

12. Про засади внутрішньої і зовнішньої політики: Закон України від 1 липня 2010 року № 2411-VI . Офріиійний Вісник України. 2010. № 55. Ст. 1840.

13. Про засади державної антикорупційної політики в Україні (Антикорупційна стратегія) на 2014-2017 роки. Відомості Верховної Ради України. 2014. № 46. Ст. 2047.

\section{References:}

1. Stetsenko, S. G. (2011) Vstup do kursu «Medychne pravo Ukrainy». Lektsiia. Pravo Ukrainy - Law of Ukraine, 11-12, 120-131. [in Ukrainian].

2. Vasechko, L. O. (2016) Mistse suchasnoho medychnoho prava u systemi prava Ukrainy. Publichne pravo - Public law, 3, 60-65. [in Ukrainian].

3. Nesterovych, V. F. (2014) Vydy vplyvu hromads'kosti na pryynyattya normatyvnopravovykh aktiv. Visnyk Luhans'koho derzhavnoho universytetu vnutrishnikh sprav imeni E. O. Didorenka - Bulletin of the Luhansk State University of Internal Affairs Didorenko, 1, 33-39. [in Ukrainian].

4. Pobudova novoi systemy hromadskoho zdorov'ia v Ukraini. Ofitsiinyi sait Ministerstva okhorony zdorov'ia Ukrainy. URL: http://www.moz.gov.ua/ua/ portal/pre_20161006_b.html. [in Ukrainian].

5. Stetsenko, V. Yu. (2010) Obov'iazkove medychne strakhuvannia v Ukraini (administratyvno-pravovi zasady zaprovadzhennia). Kyiv: Atika. [in Ukrainian].

6. Lohvynenko, B. O. (2017) Publichne administruvannia sferoiu okhorony zdorov'ia v Ukraini: teoriia i praktyka. Kyiv: «MP Lesia». [in Ukrainian].

7. Nesterovych, V. F. (2010) Osnovni pidkhody do vyznachennya ponyattya «lobiyuvannya». Visnyk Luhans'koho derzhavnoho universytetu vnutrishnikh sprav imeni E. O. Didorenka - Bulletin of the Luhansk State University of Internal Affairs Didorenko, 1, 50-58. [in Ukrainian].

8. Makushev, P. (2013) Vzayemna politychna vidpovidal'nist' derzhavnoyi vlady i hromadyanyna $\mathrm{v}$ suchasniy pravoviy derzhavi: monohrafiya / V. M. Toryanyk, P. V. Makushev (Eds.). Kherson. [in Ukrainian].

9. Pravokul'turnyye osnovy issledovaniya gosudarstvennoy vlasti: teoretikometodologicheskiye, istoriko-pravovyye i tsennostno-normativnyye aspekty: monografiya (2014). G. I. Avtsinova, V. YA. Lyubashits, A.YU. Mamychev, A.YU. Mordovtsev, A. I. Ovchinnikov (Eds.) et al. Moskva: Yurlitinform. [in Russian]. 
10. Normotvorcha diyal'nist' Prezydenta Ukrayiny ta yiyi normoproektne zabezpechennya. (2011) O.V.Skrypnyuk, V. L. Fedorenko, YU. H. Barabash, YA. O. Bernazyuk (Eds.) et al. O. V. Skrypnyuk, \& V. L. Fedorenko (Ed.). Kyiv: NADU. [in Ukrainian].

11. Konstytutsiya Ukrayiny: pryynyata na p"yatiy sesiyi Verkhovnoyi Rady Ukrayiny 28 chervnya 1996 roku. Vidomosti Verkhovnoyi Rady Ukrayiny - Information of the Verkhoona Rada of Ukraine, 30, art. 141. [in Ukrainian].

12. Pro zasady vnutrishn'oyi i zovnishn'oyi polityky: Zakon Ukrayiny vid 1 lypnya 2010 roku № 2411-VI. Ofitsiinyi visnyk Ukrainy - Official Bulletin of Ukraine, 55, art. 1840. [in Ukrainian].

13. Pro zasady derzhavnoyi antykoruptsiynoyi polityky v Ukrayini (Antykoruptsiyna stratehiya) na 2014-2017 roky. (2014) Vidomosti Verkhovnoyi Rady Ukrayiny - Information of the Verkhovna Rada of Ukraine, 46, art. 2047. [in Ukrainian].

Стаття надійшла до редколегії 03.11.2009

Сиделковський А. Л., кандидат медицинских наук, руководитель клиники «АКСИМЕД» (г. Киев, Украина)

\section{АДМИНИСТРАТИВНО-ПРАВОВАЯ СУЩНОСТЬ ПУБЛИЧНОЙ ПОЛИТИКИ В КОНТЕКСТЕ ФОРМИРОВАНИЯ ЕДИНОГО МЕДИЦИНСКОГО ПРОСТРАНСТВА УКРАИНЫ}

В статье рассматривается административно-правовая сущность публичной политики в контексте формирования единого медицинского пространства Украины. Акцентировано внимание на вопросах развития медицинского права как комплексного правового образования. Указано, что целью формирования единого медицинского пространства является надлежащее обеспечение и защита прав пациентов при оказании им медицинской помощи. Сделан вывод, что идеология современной медицинской реформы, согласно которой «деньги ходят за пациентом», имеет отношение к административно-правовым основам формирования единого медицинского пространства.

Ключевые слова: публичная политика, здравоохранение, единое медицинское пространство, медицинское право, административное право.

Sidelkovsky O.,

Candidate of Medical Sciences,

Head of AKSIMED Clinic

(Kyiv, Ukraine)

\section{THE ADMINISTRATIVE AND LEGAL NATURE OF PUBLIC POLICY IN THE CONTEXT OF FORMING A SINGLE MEDICAL SPACE IN UKRAINE}

As of today, we are witnessing a number of negative social and legal phenomena that are taking place in Ukraine, in particular: increase of morbidity, decrease in life expectancy and quality of life, decrease in the population of our country, difficulties in the legal and organizational support of health care. It seems that one of the important steps to overcome 
these negative phenomena may be to create and support the functioning of a single medical space.

The article deals with the administrative and legal nature of public policy in the context of forming a single medical space in Ukraine. As of today, there are state, communal, private and departmental medicine in the state. From the point of view of the history of Ukraine, its traditions and approaches to the legal provision of health care, this option of health care organization is justified. However, nowadays, when it comes to medical reform, the need to find ways to secure and protect patients' rights, it is important to find ways to create a single medical space.

Emphasis is placed on the development of medical law as a complex legal entity. It is stated that the purpose of forming a single medical space is to properly protect and protect patients' rights when providing them medical care. Thus, in our deep conviction, public health policy regarding the formation of a single medical space should be in the paradigm of the development of Ukrainian medical law. The administrative and legal features of public policy implementation should aim at ensuring that the average citizen of Ukraine can exercise his / her right to receive medical care regardless of his / her place of residence and belonging to a particular social group.

Key words: public policy, health care, common medical space, medical law, administrative law. 